TERMINUS

t. $22(2020)$

z. $3(56)$

s. $209-232$

www.ejournals.eu/

Terminus

\title{
Spór o kobiety w dialogu Il merito delle donne Moderaty Fonte
}

\section{Abstract \\ Women's Rules of the Game: A Dispute over Women in the Dialogue Il merito delle donne by Moderata Fonte}

This paper concerns Moderata Fonte (Modesta dal Pozzo), a female Venetian writer who lived in the 16th century, and a dialogue she wrote, Il merito delle donne (On the Value of Women), in which seven women gathered in a garden have a lively discussion about men and their flaws. The author of the study presents the book and Fonte's biography in the context of the early-modern dispute over women (querelle des femmes). She then analyses Il merito delle donne in terms of the functionality of both the genre in which it was written and the convention of play (game) that is relevant to the work, in order to answer the question of the importance of these devices for the topic Fonte raises. Skowron writes about what makes $\mathrm{Il}$ merito delle donne different from other dialogues published at the time by women, as well as from Balthazar Castiglione's famous Book of the Courtier (Il libro del Cortegiano), and in discussing the motif of the play she uses the definition of the ludic element of Johan Huizinga of Homo ludens. She points to the presence of particular determinants of play in Il merito delle donne, wondering how the voluntary basis of the game, limited time and space, imposed rules or a situation different from ordinary life affect the female characters' freedom to express their opinions in discussion, as well as the reception of the work itself. Il merito delle donne owes its unique character to its form because it allows not only different views in a dispute over women to be presented, but above all it involves the reader in a discussion which does not end with the last page of the dialogue.

\section{Keywords}

Moderata

Fonte, querelle des fermes, the women question, Johan Huizinga, dialogue 
„Drugim głosem” (the other voice) nazywają pisarstwo kobiece wczesnonowożytnej Europy literaturoznawcy, którzy zajmują się analizą i interpretacją napisanych w dawnych wiekach tekstów dotyczących wartości kobiet, ich statusu czy ról społecznych. „Drugim”, czyli słabiej dostrzeganym i często pomijanym w debacie o wykluczeniu kobiet, której źródeł można szukać znacznie wcześniej niż w ruchach emancypacyjnych z końca XVIII wieku. Jednym z ważniejszych przejawów owego „drugiego głosu” jest dialog Il merito delle donne (O wartości kobiet) włoskiej pisarki Moderaty Fonte, wydany po raz pierwszy w Wenecji w roku $1600^{1}$.

Autorka wzbudza coraz większe zainteresowanie literaturoznawców włoskich i angielskojęzycznych ${ }^{2}$, powoli też wyrasta na istotną dla włoskiego renesansu postać. Choć poświęciła kilka okolicznościowych wierszy Stefanowi Batoremu ${ }^{3}$, nie jest w Polsce znana ${ }^{4}$. Jej utwory mogą być istotne dla polskiego czytelnika nie tylko

$1 \quad$ Edycja współczesna: M. Fonte, Il merito delle donne ove chiaramente si scuopre quanto siano elle dengne e più perftte de gli uomini, a cura di A. Chemello, Venezia 1988. W 1997 roku ukazał się przekład angielski: M. Fonte, The Worth of Women: Wherein Is Clearly Revealed Their Nobility and Their Superiority to Men, ed. and transl. by V. Cox, Chicago-London 1997. Jest to jedna z pierwszych edycji w serii wydawniczej The Other Voice in Early Modern Europe poświęconej piśmienności kobiet w epoce wczesnonowożytnej. Seria ukazuje się od 1996 roku. Pracują nad nią badacze skupieni wokół uniwersytetów w Chicago i Toronto. Do tej pory ukazało się sześćdziesiąt tomów wydanych przez University of Chicago Press oraz sto trzydzieści dziewięć wydanych przez współpracujące z University of Toronto wydawnictwo Iter Press. Warto wspomnieć, że wśród opracowanych tekstów znajdują się także dzieła polskich autorek: F.U. Radziwiłłowa, Selected Drama and Verse, ed. by P.J. Corness, B. Judkowiak, transl. by P.J. Corness, translation editor A. Zwierzyńska-Coldicott, introd. by B. Judkowiak, Toronto 2015; A. Stanisławska, Orphan Girl: A Transaction, or an Account of the Entire Life of an Orphan Girl by Way of Plaintful Threnodies in the Year 1685. The Aesop Episode, verse transl., introd., and comment. by B. Keane, foreword by M.L. King, Toronto 2016; w przygotowaniu: R.S. Pilsztynowa, My Life's Travels and Adventures: An Eighteenth-Century Oculist in the Ottoman Empire and the European Hinterland, ed. and transl. by W. Roczniak; A. Stanisławska, One Soul, One Body, One Heart: An Epic Tale of Married Love in Seventeenth-Century Poland, verse transl., introd., and comment. by B. Keane.

2 Nazwisko Fonte pojawia się w większości prac dotyczących wczesnonowożytnej literatury pisanej przez kobiety (A. Romagnoli, V. Cox, T. Plebani, J.L. Smarr). Staje się nawet punktem odniesienia dla pisania o literaturze kobiet $\mathrm{w}$ Wenecji, będącej centrum wydawniczym włoskiego renesansu, por. D. Martelli, Polifonie: le donne a Venezia nelletà di Moderata Fonte (seconda metà del secolo 16.), Padova 2011.

3 Utwory zebrano w okolicznościowym zbiorze Del giardino de’poeti, in lode del Serenissimo Re di Polonia, Gran Duca di Littuania, Russia, Prussia, Samogita, e Chiouia, Signor di Libonia e Prencipe di Transilvania wydanym w Wenecji w 1583 roku (s. 14; 48-57); numeracja podana w spisie treści (Catalogo degli autori) nie odpowiada numerom kolejnych stron starodruku. Utwory Fonte pojawiają się na stronach o numerach: 48, 50, 51, 50, 51, 53-57. O zbiorze wspomina Juliusz Nowak-Dłużewski, Okolicznościowa poezja polityczna w Polsce. Pierwsi królowie elekcyjni, Warszawa 1969, s. 157-159. Badacz podkreśla wyróżniający się na tle pozostałych utworów autorów cyklu refleksyjny charakter wierszy Moderaty Fonte.

4 Warto jednak odnotować, że wspomina o niej Maria Bogucka w swej książce Gorsza płeć. Kobieta w dziejach Europy od antyku po wiek XXI, Warszawa 2005, s. 128-129, a także Jakub Niedźwiedź w recenzji książki Meredith K. Ray, Daughters of Alchemy, „Terminus” 18 (2016), z. 3 (40), s. 301-309. 
ze względu na te wiersze. Szczególnie istotne są dwa inne dzieła autorki: poemat rycerski Tredici canti del Floridoro i wspomniany już dialog Il merito delle donne. Prezentowany artykuł jest pierwszym polskim omówieniem tego ostatniego. Moim głównym celem jest przybliżenie sylwetki weneckiej pisarki i przedstawienie jej znaczenia we wczesnonowożytnym - a więc również polskim - tak zwanym sporze o kobiety (querelle des femmes) ${ }^{5}$.

Istotne dla dalszych studiów może się również okazać uzupełnienie polskiego stanu badań nad renesansowym sporem o kobiety, a także próba odpowiedzi na pytanie, czy dialog Moderaty Fonte wyróżnia się na tle innych głosów angażujących się w literacką wymianę poglądów na temat kobiet w Europie, zwłaszcza w bliskim dla autorki kontekście kultury szesnastowiecznej Italii. Tekst dialogu zostanie omówiony ze szczególnym uwzględnieniem formy, w jakiej został przedstawiony czytelnikowi, oraz istotnej dla dzieła konwencji zabawy (gry). Posłuży do tego definicja zabawy (ludus) autorstwa Johana Huizingi ${ }^{6}$. Teoria holenderskiego badacza kultury pomoże w refleksji nad odpowiedzią na pytanie o to, jaką rolę dla wymowy dialogu i jego znaczenia w querelle des femmes odgrywa sposób przedstawienia rozmowy bohaterek przez Moderatę Fonte.

5 Za początek omawianego zjawiska uznaję pierwsze teksty pisane „w obronie kobiet”, por. V. Cox, Moderata Fonte and "The Worth of Women", w: M. Fonte, The Worth of Women..., s. 12. Pisząc o querelle des femmes, Michaił Bachtin ogranicza to zjawisko do Francji i lat 1542-1550, dodając: „Nie był to spór nowy: burzył umysły już w XV wieku, a w istocie interesowało się nim całe średniowiecze" (M. Bachtin, Twórczość Franciszka Rabelais'go a kultura średnioweicza i renesansu, przeł. A. i A. Goreniowie, oprac. S. Balbus, Kraków 1975, s. 345). Bachtin wskazuje tym samym, że problematyka kobieca dotyczyła także wcześniejszych twórców. Szczegółowe opracowanie zagadnienia: A. Romagnoli, La donna del Cortegiano nel contesto della tradizione (Tesis de Doctorato, Universidad de Barcelona 2009); T. Plebani, Le scritture delle donne in Europa. Pratiche quotidiane e ambizioni letterarie (secoli XIII-XX), Roma 2019. Staram się traktować wczesnonowożytny spór o kobiety jak najszerzej, poświęcając szczególną uwagę tekstom bliskim Moderacie Fonte czasowo, zwłaszcza literaturze włoskiej tego okresu; por. V. Cox, Women’s Writing in Italy 1400-1650, Baltimore 2008; eadem, The Prodigious Muse: Women's Writing in Counter-Reformation Italy, Baltimore 2011; J. Levarie Smarr, Joining the Conversation: Dialogues by Renaissance Women, Michigan 2005; T. Plebani, Scritture delle donne nel rinascimento italiano, w: Il Rinascimento Italiano e l'Europa, vol. 2: Umanesimo ed educazione, a cura di G. Belloni, R. Drusi, Vicenza 2007, s. 243-263; T. Plebani, Il "genere» dei libri. Storie e rappresentazioni della lettura al femminile e al maschile tra Medioevo ed età moderna, Milano 2001; G. Conti Odoriso, Donna e societa nel Seicento. Lucrezia Marinelli e Arcangela Tarabotti, Roma 1979. Spośród polskich badaczy o querelle des femmes pisali między innymi: J. Partyka, „Żona wyćwiczona”. Kobieta piszaca w kulturze XVI i XVII wieku, Warszawa 2004; M. Uliński, Kobieta i mężczyzna. Dzieje refleksji filozoficzno-społecznej, Kraków 2001; M. Bogucka, Gorsza płeć..., s. 115-144.).

6 Wybór koncepcji Johana Huizingi (Homo ludens. Zabawa jako źródło kultury, przeł. M. Kurecka, W. Wirpsza, Warszawa 1985) jako narzędzia metodologicznego służy uwypukleniu konkretnego aspektu dzieła Fonte; por. także R. Callois, Gry i ludzie, przeł. A. Tatarkiewicz, M. Żurowska, Warszawa 1997; B. Sutton-Smith, The Ambiguity of Play, Cambridge (Mass.) 1997; V. Turner, From Ritual to Theatre: The Human Seriousness of Play, New York 1982. 


\section{Moderata Fonte - życie i twórczość}

Historię życia przyszłej autorki Il merito delle donne można odtworzyć dzięki Niccolò Doglioniemu, który spisał jej biografię w 1593 roku. Została ona wydrukowana jako przedmowa do dialogu i jest głównym źródłem informacji na temat losów Fonte oraz jej twórczości ${ }^{7}$. Pisarka urodziła się 15 czerwca 1555 roku $^{8}$ w rodzinie cittadini originari veneziani, najwyższej po patrycjacie warstwie społecznej Wenecji, jako Modesta Pozzo. Nom de plume autorki z imieniem sugerującym umiejętność zmiany i płynność, ale też powściągliwość i łagodność, oraz nazwiskiem oznaczającym źródło pozwala sądzić, że Moderata Fonte była świadomą swojej wartości autorką.

Autor biografii, Niccolò Doglioni (1548-1629), to postać szanowana w środowisku literackim skupionym wokół Akademii Weneckiej. Co istotnie, był też wujem pisarki. Przypuszcza się, że dzięki niemu mogła zaistnieć w literackim świecie?. Moderata Fonte wspomina wuja w omawianym dialogu w wypowiedzi jednej z bohaterek, Corinny, która mówi o nim podczas dyskusji dotyczącej mężczyzn zajmujących się astrologią. Nie powstrzymuje się co prawda przed tym, by wspomnieć, że „życzliwość i oddanie” Doglioniego to cechy niezwykle rzadko spotykane u płci przeciwnej, jednak w jej wypowiedzi przeważa ton pochwalny:

E egli capace di molte scienze, ha composto molti libri e tra l'altre avendosi dilettato di questa, oltra la principal sua professione, ne ha trattato un bellissimo discorso particolare pur intorno a questa materia de stagione de' tempi e cose simili intitolato, L'Anno $[\ldots]^{\mathbf{1 0}}$.

[To mężczyzna wszechstronnie wykształcony, biegły nie tylko w swojej dziedzinie. Napisał wiele książek, a jedną z nich, pod tytułem L’Anno, poświęcił pięknej opowieści między innymi o porach roku i pogodzie].

Pochwałę Doglioniego wieńczy wygłoszony przez bohaterkę sonet na jego cześć, w którym uczony staje się natchnionym, boskim wieszczem - odszyfrowuje znaki niebios i dzierży władzę nad naturą i sztuką.

Jak Fonte przedstawia swojego protektora w świetle cnót i zasług, tak i uczony pisze o siostrzenicy jako o wyjątkowo uzdolnionej i nieprzeciętnej kobiecie ${ }^{\mathbf{1 1}}$. „Niezwykły

$7 \quad$ N. Doglioni, Vita della signora Modesta Pozzo de Zorzi nominata Moderata Fonte descritta da gio. Nicolò Doglioni l'anno M. D. XCIII, w: M. Fonte, Il merito..., s. 3-10.

$8 \quad$ Por. M. Vigliante, Dal Pozzo, Modesta, w: Dizionario Biografico degli Italiani, vol. 32 (1986), http:// www.treccani.it/enciclopedia/modesta-dal-pozzo_(Dizionario-Biografico) (dostęp: 31.05.2019).

$9 \quad$ M.K. Ray, Daughters of Alchemy: Women and Scientific Culture in Early Modern Italy, Cambridge (Mass.) 2015, s. 77.

10 M. Fonte, Il merito..., s. 84. Wszystkie tłumaczenia, o ile nie zaznaczono inaczej, są mojego autorstwa. Dalej odnotowuję tylko odpowiednie strony cytowanego wydania.

11 Doglioni przytacza między innymi anegdotę o tym, jak podczas podróży ze swoim opiekunem, Prosperem Saracenim, mała Moderata upuściła do rzeki Piawy koszyk ze swym ówczesnym literackim 
wybryk natury"12 - podobno w ten sposób określano młodą Modestę w klasztorze Santa Maria, gdzie jeden z krewnych umieścił dziewczynkę wbrew jej woli. W wieku dziewięciu lat powróciła do domu Prospera Saraceniego, u którego mieszkała po śmierci rodziców (została osierocona, gdy miała zaledwie rok ${ }^{\mathbf{1 3}}$ ). Dom Saraceniego sprzyjał intelektualnemu rozwojowi, gdyż gospodarz był żywo zainteresowany literaturą. W takim środowisku młoda pisarka mogła z powodzeniem szlifować swoje talenty: znała łacinę, potrafiła rysować, grać na lutni i klawesynie. Jej pęd do nauki był tak duży, że zmuszała swojego brata do powtarzania jej wszystkiego, czego dowiedział się w szkole. Niektórzy wątpili nawet w to, czy taka osoba jak Moderata istnieje: „Moderata Fonte to młoda dziewczyna, szanowana obywatelka miasta, wykształcona we wszystkich dziedzinach tak doskonale, jak to tylko możliwe (choć, tak na dobrą sprawę, nikt nie potwierdził, że widział ją osobiście)"14 - taką wypowiedź za przewodnikiem po Wenecji Francesca Sansovina przytacza autorka wstępu do angielskiego wydania dialogu o wartości kobiety, Virginia Cox.

Fonte była znana i doceniana w literackim środowisku. W jednym z wydań popularnego przewodnika, Delle cose notabili della città di Venezia (Osobliwości miasta Wenecji ${ }^{\mathbf{1 5}}$ poświęcono siedem stron literatom, wśród których znajdują się tylko dwie kobiety, Casandra Fedele i właśnie Moderata Fonte; w późniejszej edycji do tego grona dołączyła Lucrezia Marinella ${ }^{\mathbf{1 6}}$. W literaturze przedmiotu wspomina się jeszcze między innymi o Gasparze Stampie i Veronice Franco, które wymieniały listy i wdawały się w dysputy z uczonymi. Autorka wstępu do włoskiego wydania dialogu Fonte, Adriana Chemello, zaznacza jednak, że choć Moderata Fonte i Veronica Franco były w tym samym wieku, żyły w tym samym mieście, a także otaczała je ta sama kultura, nie miały okazji, by się spotkać. Podczas gdy Franco mogła obcować z wybitnymi petrarkistami osobiście, Fonte, zajęta domem, skazana była na kontakt $\mathrm{z}$ nimi wyłącznie przez lekturę ${ }^{17}$.

Poświęcenie się domowym obowiązkom nie sprawiło, że Fonte zaniechała pisania. Doglioni zwraca uwagę, że to codzienne zajęcia, związane chociażby z opieką nad dziećmi, zdecydowanie ograniczyły jej działalność literacką. Wspomina o natłoku domowych zadań i, co ważne, fałszywym społecznym przekonaniu, że „kobiety nie odnoszą sukcesów w niczym poza prowadzeniem domu”18. Tłumaczy w ten sposób

dobytkiem. Rodzina „nie mogła znaleźć sposobu”, by uspokoić zdruzgotaną dziewczynkę. Ta, obdarzona ponadprzeciętną pamięcią, zdołała jednak wszystko odtworzyć; por. N. Doglini, Vita della signora..., s. 6.

12 Ibidem, s. 5.

13 Por. M. Vigilante, Dal Pozzo...

14 V. Cox, Moderata Fonte..., s. 4.

15 G. Bardi, Delle cose notabili della città di Venetia, Venetia: Felice Valgrisi, 1587, https://archive.org/ details/imageGXII204NarrativaOpal/page/n9 (dostęp: 1.06.2019).

16 A. Chemello, Il nuovo «canone di lettura» di Luisa Bergalli: «I Componimenti poetici piu illustri Rimatrici d’ogni secolo", w: Voci e figure di donne. Forme della rappresentazione del sé tra passato e presente, a cura di L. Fortini, M. Sarnelli, Cosenza 2012, s. 161.

17 A. Chemello, Gioco e dissimulazione in Moderata Fonte, w: M. Fonte, Il merito..., s. 12.

18 N. Doglioni, Vita della signora..., s. 9. 
fakt, że Moderata nie miała prawdopodobnie czasu na przeczytanie napisanego dialogu i wprowadzanie jakichkolwiek poprawek do tekstu, a czytelnik dostaje do ręki pierwszą wersję dzieła, które zostało podobno ukończone na dzień przed śmiercią autorki. Okoliczności powstania książki pozwalają więc traktować ją jako pewnego rodzaju literacki testament.

Dialog O wartości kobiet (Il merito delle donne) ukazał się w 1600 roku, osiem lat po śmierci autorki; zmarła przy porodzie czwartego dziecka. Epitafium napisane przez męża, prawnika Filippa Zorziego, upamiętnia ją jako poetkę i wysławia głównie jej talent literacki. Osiągnęła bowiem wyjątkowy jak na kobietę sukces: była autorką między innymi wspomnianego już, wzorowanego na Orlandzie szalonym romansu rycerskiego (Tredici canti del Floridoro), poetyckiego przedstawienia śmierci i zmartwychwstania Chrystusa (La Passione di Christo; La Resurrezione di Gesu Christo), dzieła na cześć weneckiego doży (Le feste: rappresentatione avanti il Serenissimo Prencipe di Venetia $)^{\mathbf{1 9}}$ oraz wielu krótkich utworów poetyckich, wydanych zdaniem Doglioniego anonimowo. Warto także dodać, że nie wiadomo prawie nic o licznych manuskryptach, które jak podaje autor biografii, miała pozostawić Fonte. Nie jest więc możliwe oszacowanie, jaką częścią literackiego dorobku pisarki są opublikowane i znane dziś tytuły ${ }^{20}$.

Utwór $O$ wartości kobiet to podzielony na dwie części (odpowiadające dwóm dniom) dialog, w którym uczestniczy siedem kobiet. Zebrane w Wenecji w ogrodzie jednej z nich, Leonory, decydują się na dysputę, w której jedna ze stron sporu broni mężczyzn, podczas gdy druga wylicza ich wady i niedoskonałości. Najstarsza ze zgromadzonych, Adriana, jednomyślnie i dobrowolnie wybrana na prowadzącą, dzieli grupę na dwa obozy i rozdziela role, przyporządkowując każdą z pań do jednego z dwóch stronnictw. Elena, Virginia i Lucrezia wcielają się więc w obrończynie mężczyzn. W roli oskarżycielek występują: Corinna, Cornelia i Leonora. Bohaterki dyskutują, odwołując się do własnego doświadczenia i przykładów z literatury, czym potwierdzają, że otrzymały solidne wykształcenie. Ubarwiają dyskusję recytowaniem wierszy czy grą na klawesynie. Dzień pierwszy kończy się pytaniem o to, dlaczego kobiety wciąż kochają mężczyzn pomimo ich wielu wad. Próbę znalezienia na nie odpowiedzi kolejnego dnia, gdy bohaterki spotykają się ponownie, przerywają liczne dygresje. Drugi dzień poświęcony dyskusji wyraźnie różni się od pierwszej części dialogu. Dominują rozmowy o świecie przyrody i domowych doświadczeniach: o gatunkach roślin, zwierząt, zjawiskach meteorologicznych czy kosmetykach. Amerykańska badaczka, Virginia Cox, upatruje w tym wyrazu popularnej w czasach Fonte ambicji, aby „zamknąć całość wiedzy na kartach jednej książki”21. Zbliża to drugą część utworu do tematyki poczytnych wówczas libri di segreti. Powiązanie tak rozumianych sekretów (czyli eksperymentów, przepisów na radzenie sobie w domu

19 S. Ross, Fonte, Moderata (Modesta da Pozzo, 1555-1592), w: Encyclopedia of Women in the Renaissance: Italy, France and England, ed. by D. Robin, A.R. Larsen, C. Levin, Santa Barbara-Denver-Oxford 2007, s. 151. 
na przykład z rozmaitymi chorobami) z doświadczeniem zdobywanym przez żony i matki w codziennych obowiązkach było „na tyle dominujące, że filozofia naturalna stała się integralną częścią renesansowej dyskusji nad kobietami”22.

Tuż przed wydaniem dialogu Fonte, w 1599 roku, ukazała się rozprawa Giuseppe Passiego I donneschi difetti (Wady kobiet), w której porównano zajmowanie się medycyną i zainteresowanie nauką do czarów ${ }^{23}$. Il merito delle donne wraz z La nobiltà ed eccelenza delle donne co'difetti e mancamenti de gli uomini (Szlachectwo i doskonałość kobiet oraz defekty i ułomności mężczyzn) Lucrezii Marinelli uznawane są za odpowiedź na utwór Passiego ${ }^{\mathbf{2 4}}$, który nie widział dla kobiet miejsca w nauce. Tekst cieszył się jednak sporą popularnością - został przedrukowany trzykrotnie ${ }^{25}$.

\section{Wczesnonowożytny spór o kobiety}

Podtytuł dialogu Fonte (ove chiaramente si scuopre quanto siano elle degne e più perfette de gli uomini, „gdzie w oczywisty sposób ujawnia się, o ile bardziej godne są [kobiety] od mężczyzn i doskonalsze od nich") oddaje charakter ówczesnej debaty na temat kobiet, w której przerzucano się argumentami mającymi dowieść wyższość jednej z płci nad drugą. W dyskusji zawartej w Il merito delle donne odnaleźć można wiele z prezentowanych wówczas stanowisk. Badacze tej problematyki w kulturze wczesnej nowożytności piszą najczęściej o querelle des femmes, sporze o kobiety, bądź kwestii kobiecej (the women question). Jej początki często datuje się na koniec XIV wieku, kiedy Giovanni Boccaccio napisał De claris mulieribus (O słynnych kobietach), „katalog” wyróżniających się odwagą niewiast. Podobne wyliczenie tworzą bohaterki Moderaty Fonte, które powołują się na przykłady walecznych kobiet, aby zilustrować tezę:

[...] si è visto chiaro di quelle che sono state già tempo allevate sotto tal disciplina, quanto son riuscite valorose ed esperte, avvendo appresso quel particolar e proprio dono del presto conseglio, co'l quale hanno avvanzato gli uomini in mille occasioni [...] (s. 62).

[widać wyraźnie, jak zdolne i chwalebne są te, które były od długiego czasu wychowywane w dyscyplinie; dzięki temu zyskały ów wyjątkowy i właściwy im dar szybkiego myślenia, którym wielokrotnie pokonują mężczyzn].

22 M.K. Ray, Daughters of Alchemy..., s. 72.

23 Ibidem, s. 74. Omówienie dzieła Passiego zob. F. Boni, "VII: Foetorem in lecto» Una lettura de "I donneschi difetti” di Giuseppe Passi Ravennante, „Studia Litteraria Universitatis Iagellonicae Cracoviensis” 5 (2010), issue 1, s. 25-36.

24 Por. analizę porównawczą tekstów Fonte i Marinelli w kontekście dzieła Passiego: S. Kolsky, Moderata Fonte, Lucrezia Marinella, Giuseppe Passi: An Early Seventeenth-Century Feminist Controversy, „The Modern Language Review" 96 (2001), no. 4, s. 973-989.

25 M.K. Ray, Daughters of Alchemy..., s. 74. 
Podobnie jak Boccaccio wymieniają między innymi rzymską królową Kamilę, która zasłynęła walecznością na polu bitwy, egipską władczynię Kleopatrę, Orejtyję dowodzącą Amazonkami czy Zenobię, królową Palmiry.

Zbiór przykładów mogących służyć za argument na rzecz uczestnictwa kobiet w życiu politycznym miał jednak pewien mankament, wyjątkowość niewiast przejawiała się bowiem w ich „niekobiecości”; były warte upamiętnienia o tyle, o ile mogły wykroczyć poza swoją płeć ${ }^{26}$. O kobietach wypowiadał się wciąż mężczyzna, a narracja u Boccaccia pełna jest odautorskich komentarzy, w których pobrzmiewa niechęć do pozwolenia kobietom na realizacje ich marzeń - jak chociażby wtedy, gdy Boccaccio pisze, że chciałby, aby „zrozumiały, iż jest niegodne i nie licuje z czystością obyczajów pragnienie tego, co się podoba, i czynienie, na co przyjdzie ochota"27.

Jako pierwsza na brak obiektywizmu opowiadających o kobietach mężczyzn otwarcie wskazała Christine de Pisan $^{\mathbf{2 8}}$ - pierwsza znana nam kobieta, która zarabiała na życie pisaniem. Jej powstały około 1405 roku utwór Le Livre de la Cité des Dames (Książka o mieście kobiet) obfituje w przykłady kobiet przeczące stereotypom popularyzowanym między innymi przez średniowieczną Roman de la Rose (Powieść o Róży). Z tym alegorycznym poematem Christine de Pisan odważnie polemizowała wcześniej w L’Épistre au Dieu d’amours (Liście do Boga miłości) ${ }^{\mathbf{2 9}}$. Książka o mieście kobiet przedstawia rozmowę autorki (Pani Prawość) z Panią Rozumem i Panią Sprawiedliwością. Jest utopijną wizją idealnego miasta, zamieszkanego przez kobiety. Pisan poszerza „katalog” Boccaccia o życiorysy chrześcijanek ${ }^{\mathbf{3 0}}$, a ponadto, niejako sytuując się w opozycji do autora De claris mulieribus, prezentuje kobiece cnoty jako uniwersalne, niebędące wyjątkami od reguły ${ }^{31}$.

Tekstów w obronie kobiet pisano tak dużo, że traktowano je niemal jak odrębny gatunek $^{32}$. Do tych najczęściej cytowanych, jak twierdzi Maciej Uliński, należała De nobilitate et praecellentia foeminei sexus z 1529 roku (Książeczka o szlachetności i zacności płci niewieściej i jej przewadze nad płcia męską), napisana przez Heinricha Corneliusa Agrippę von Nettesheim ${ }^{33}$. Dowodów na przewagę kobiet szukał on już w Biblii, a jednym z kluczowych wątków querelle des femmes uczynił dyskusję

26 Także „późniejsze” bohaterki, słynne włoskie poetki czy postaci z literatury (np. z eposów Boiarda i Ariosta) były znane ze względu na swoją „męskość”: naśladowanie pisanej przez mężczyzn poezji czy dokonywanie walecznych czynów. Według Jacoba Burkhardta, „Na chwałę ówczesnych wielkich Włoszek nie można było powiedzieć nic pochlebniejszego ponad to, że miały męski umysł i męskiego ducha”, J. Burkhardt, Kultura odrodzenia we Włoszech, przeł. M. Kreczkowska, Warszawa 1991, s. $240-241$. G. Boccaccio, O słynnych kobietach, przeł. i oprac. P. Bańkowski, I. Grześczak, A. Szopińska, Warszawa 2013, s. 229.

28 V. Cox, przypis nr 43, w: M. Fonte, The Worth of Women..., s. 77.

29 Por. J. Partyka, „Żona wyćwiczona”..., s. 97.

$30 \quad$ Por. M. Uliński, Kobieta i mężczyzna..., s. 81.

31 Por. M.J. King, A. Rabil Jr, The Other Voice in Early Modern Europe: Introduction to the Series, w: M. Fonte, The Worth of Women..., s. 18.

32 Zob. V. Cox, Moderata Fonte..., s. 13.

33 Por. M. Uliński, Kobieta i mężczyzna..., s. 83. 
wokół Ewy, pierwszej kobiety. W dialogu Fonte jego argumentacja włożona została w usta Corinny:

Sono nati inanzi di noi - rispose Corinna - non per dignità loro, ma per dignità nostra; poiché essi nacquero dell'insensata terra perché noi poi nascessimo della viva carne e poi, che rileva quel nascer inanzi? Prima si gettano le fondamenta in terra di niun valore o vaghezza, e sopra vi s'ergono poi le sontuose fabriche, con gli adorni palagi; in terra si nutriscono prima vili semente, donde poi s'aprono i soavissimi fiori ed apparono le vaghe rose e gli odorati narcisi (s. 26).

[Urodzili się przed nami - odpowiada Corinna - nie ze względu na swoją godność, ale ze względu na naszą; oni zrodzili się bowiem z pozbawionej zmysłów ziemi, podczas gdy my pochodzimy z żywego ciała. O czym więc świadczy to nasze późniejsze pojawienie się na świecie? Najpierw wznosi się w ziemi zwyczajne, pozbawione wartości fundamenty, na których potem buduje się okazałe budowle czy ozdobne pałace. W ziemi skrywają się też najpierw małowartościowe ziarna, z których potem wyrastają jednak najsłodsze kwiaty i ukazują się wdzięczne róże oraz pachnące narcyzy].

Argument ten był w querelle des femmes poparty także znaczeniem imion pierwszych ludzi. Adam ('ziemia') konfrontowany był z ‘życiem’, które kryło się za imieniem jego towarzyszki ${ }^{34}$. Etymologia była jedną z tych strategii argumentacyjnych, do których odwoływali się uczestnicy wczesnonowożytnego sporu o kobiety. Przykładowo, w zależności od tego, czy zamierzano ukazać wady kobiet, czy udowodnić ich zalety, przedstawiano pochodzenie słowa donna od danno, oznaczającego 'krzywdę, bądź też od domina, określenia dzierżącej władzę pani domu ${ }^{35}$, a źródeł łacińskiego słowa mulier dopatrywano się w słowie molis ('słaby', 'delikatny') albo melior ('lepszy', 'doskonalszy') ${ }^{\mathbf{3 6}}$.

Kluczowa dla sporu o kobiety była także kwestia edukacji. Piszą o niej tacy humaniści jak Erazm z Rotterdamu ${ }^{37}$ czy Juan Luis Vives ${ }^{\mathbf{3 8}}$, który w swojej książce przedstawił zacne niewiasty ${ }^{39}$, aby potwierdzić tezę, że wykształcone kobiety nigdy nie były złe ${ }^{40}$. W dialogu Fonte wątek ten zauważalny jest we wspomnianych już rozmowach bohaterek o nauce, które mogą służyć poparciu kobiecych aspiracji przez uczestniczących w querelle des femmes myślicieli. Dzieło Moderaty Fonte jest

34 V. Cox, przypis nr 24, w: Moderata Fonte, The Worth of Women..., s. 60.

35 Zdania na ten temat wymieniają Leonora z Cornelią (M. Fonte, Il merito..., s. 55).

36 F. Boni, «VII: Foetorem in lecto»..., s. 28.

37 Erasmus on Women, ed. by E. Rummel, Toronto-Buffalo-London 1996.

38 Na temat stosunku hiszpańskiego humanisty do kobiet, por. Ch. Fantazzi, Vives and the "emarginati", w: A Companion to Juan Luis Vives, Leiden-Boston 2008, s. 65-111.

39 Książka De institutione feminae chrisianae napisana została w 1523 roku na prośbę Katarzyny Aragońskiej z myślą o wychowaniu jej córki, Marii. Tekst opracowany przez Ch. Fantazziego ukazał się w serii The Other VoiceiIn Early Modern Europe (Chicago-London 2000). 
więc częścią żywej, angażującej twórców od stuleci debaty literackiej, która w XVI wieku za sprawą coraz większej liczby sięgających po pióro kobiet ${ }^{41}$ i reagujących na to zjawisko mizoginistycznymi traktatami mężczyzn ${ }^{\mathbf{4 2}}$ zyskała niespotykany dotąd charakter. Jak pisze Fabio Boni, „Wiek XVI [...] przyniósł ze sobą nieznany wcześniej $\mathrm{w}$ świecie literatury i ogólnie świata intelektualnego fenomen: kobieta, dotychczas przedmiot literatury, staje się jej podmiotem" ${ }^{\mathbf{4 3}}$.

\section{Kobiece reguły gry}

\section{Forma tekstu i forma gry}

Wenecka autorka dokonuje ciekawych zabiegów formalnych, wyróżniających ją na tle wielogłosowej debaty o kobietach. Wybór popularnego w czasach renesansu dialogu wydaje się istotny dla odbioru dzieła i czyni głos Fonte wartym szczególnej uwagi. Użycie formy odwołującej do tradycji platońskiej i cyceroniańskiej było deklaracją współuczestnictwa w wielkiej wymianie myśli, zapoczątkowanej już w czasach starożytnych; tym bardziej ambitną, gdy weźmiemy pod uwagę to, że kobiety, których obecność w literackim środowisku nie zdążyła się jeszcze ugruntować, wybierały zazwyczaj dla ukazania swojego talentu inne gatunki. Na początku wśród uprawianych przez nie form dominowały liryki, zgodnie z paradygmatem petrarkistowskim ${ }^{\mathbf{4 4}}$. Choć z czasem pisarki zaczęły częściej sięgać po dialog - na tyle, że współcześnie powstają prace poświęcone wyłącznie renesansowym dialogom pisanym przez kobiety $^{\mathbf{4 5}}$ - był to gatunek wciąż uznawany za „męski”. Moderata Fonte jako autorka dialogu czy romansu rycerskiego Tredici canti del Floridoro wyróżniała się na tle autorek tworzących poezję miłosną lub piszących listy.

Jej utwór cechuje także pewne nowatorstwo, jeśli chodzi o sposób podejścia do dialogu jako gatunku. W przeciwieństwie do dialogów z czasów antycznych, jak i niezwykle ważnego dla kultury europejskiej dialogu Il libro del cortegiano Baldassara

41 V. Cox, Women's Writing in Italy...; T. Plebani, Le scritture delle donne in Europa...; Encyclopedia of Women in the Renaissance...; The Cambridge Companion to Early Modern Women's Writing, ed. by L.L. Knoppers, Cambridge 2009.

42 F. Boni, «VII: Foetorem in lecto»... Oprócz traktatu Giuseppe Passiego Boni wymienia liczne dzieła wymierzone przeciw kobietom: Flagello delle meretrici Giovanniego Antonia Massinoniego (1599, wydane w 1605 w Wenecji), Contro il lusso donnesco Francesca Buoninsegnego (Venezia 1644), dialog Il cavaliere e la dama kardynała Giovanniego Battisty De Luca (Roma 1675), La femmina origine d’ogni male Bonaventury Tondiego (Venezia 1687). Oprócz włoskich przykładów autor przywołuje także przypisywany Acidaliusowi Valensowi traktat Disputatio periucunda qua anonymus probare nititur mulieres homines non esse, w którym podważa się przynależność kobiet i mężczyzn do tego samego gatunku.

43 F. Boni, «VII: Foetorem in lecto»..., s. 32.

44 Por. A. Chemello, Gioco e dissimulazione..., s. IX.

45 Na przykład książka J. Levarie Smarr, Joining the Conversation... 
Castiglionego, w którym uczestnikami dyskusji są współczesne autorowi postaci historyczne, Fonte tworzy bohaterki fikcyjne. Wrażenie autentyczności tekstu uzyskane jest przez częste wspominanie o żyjących osobach (np. o Niccolò Doglionim czy ówczesnym doży weneckim, Pasquale Cicogna) oraz ważnych dla miasta wydarzeniach (zakończenie renowacji mostu Rialto ${ }^{46}$ ).

Tekst wyróżnia się przede wszystkim udzieleniem głosu kobietom. Ten aspekt dialogu warto skonfrontować ze wspomnianą już Książką o dworzaninie (Il libro del cortegiano). Dzieło to poświęca damom wiele miejsca, uznaje się, że wraz z Dekameronem Giovanniego Boccaccia miało duży wpływ na Fonte ${ }^{47}$. Zebrani na dworze w Urbino bohaterowie Castiglionego poświęcają część żywej dyskusji o doskonałym cortegiano na rozważania nad cechami idealnej damy dworu, a moderatorkami debaty są kobiety: najpierw księżna Elżbieta Gonzaga, potem wyznaczona wcześniej przez nią Emilia Pia. Choć występowanie w roli przedmiotu dyskusji czy osoby dbającej o jej spokojny przebieg niekoniecznie musiało być w pełni dla kobiet satysfakcjonujące, Castiglione, pozwalając damom przysłuchiwać się tej debacie, decyduje się na odważny zabieg. Janet Levarie Smarr stwierdza:

Podczas gdy współczesnych czytelników razi milczenie kobiet u Castiglionego, współczesnych mu odbiorców zdecydowanie bardziej prawdopodobnie raził fakt, że kobiety w ogóle były obecne, zwłaszcza podczas dyskusji dotyczących polityki ${ }^{48}$.

To, zdawałoby się, dowartościowanie kobiet traci jednak swój wyjątkowy charakter, gdy dostrzeżemy, że zachowanie bohaterek niekoniecznie współgra z przypisywaną Castiglionemu przychylnością dla dam, a obecne podczas dyskusji kobiety wcale nie odgrywają w niej znaczącej roli.

A gdy tak widzę damy siedzące tu cicho i znoszące cierpliwie te wasze zniewagi, to uświadamiam sobie, jak prawdziwe było to, co powiedział pan Oktawian, a mianowicie, iż nie przejmują się tym, co jeszcze złego o nich powiedziano, pod warunkiem, iż nie cierpią na poczucie braku cnoty ${ }^{49}$

- mówi Pan Bernard, na co obecne w sali kobiety reagują śmiechem i podbiegają do mężczyzny, „jakby pragnąc obsypać go kuksańcami”" ${ }^{\text {i }}$ i tym samym rzekomo

46 Wspomnienie o tej ważnej dla miasta inwestycji oraz doży panującym w latach 1585-1595 jest tė̇ istotną wskazówką dla ustalenia czasu powstania utworu, który mógł zostać napisany - wbrew legendzie o kończeniu teksu tuż przed śmiercią autorki w 1592 roku - już pod koniec lat osiemdziesiątych; por. A. Chemello, Gioco e dissimulazione..., s. XVIII.

47 J. Levarie Smarr, Joining the Conversation..., s. 190. Ciekawe jest też porównanie utworu Fonte z dialogiem Pietra Bemba, Gli Asolani, por. E. Carinci, Canone, gender genere letterario: "Il merito delle donne» di Moderata Fonte, w: Dentro/Fuori Sopra/Sotto. Critica femminista e canone letterario negli studi di italianistica, Ravenna 2007.

48 J. Levarie Smarr, Joining the Conversation..., s. 17.

49 B. Castiglione, Książka o dworzaninie, przeł. A. Borowski, Kraków 2018, s. 225-226.

$50 \quad$ Ibidem, s. 226. 
dowodząc, że nie jest im obojętne, jak są przez mężczyzn postrzegane i traktowane. Pani Emilia zaś w obronie godności kobiet prosi o pomoc „niezmęczonego kawalera” i wyznacza Juliana il Magnifico do zabrania głosu w tej sprawie. Ponadto, gdy mężczyźni nawiązują w dyskusji do Arystotelesowskiej metafizyki i rozważają zagadnienia materii i formy w kontekście relacji damsko-męskich, Emilia Pia przerywa im i mówi:

Na miłość boską, dajcie sobie bodaj na chwilę spokój z tymi „materiami” i „formami”, a także męskością i kobiecością, a mówcie w taki sposób, żeby można było was zrozumieć; nasłuchaliśmy się bowiem i bardzo dobrze pojęliśmy całe to zło, które nam przypisali pan Oktawian i pan Gaspar, teraz jednak zupełnie nie pojmujemy, jakim sposobem nas bronicie ${ }^{\mathbf{5 1}}$.

Nie dość więc, że nie jest w stanie sama zabrać głosu w swojej sprawie i potrzebuje do tego obrońcy, niechęcią do roztrząsania trudniejszych zagadnień tylko utwierdza obraz kobiety, dla której nie ma miejsca w środowisku intelektualnym. Na tym tle dużo wyraźniejsza staje się oryginalność dialogu Moderaty Fonte, w którym o wartości kobiet mówią wyłącznie kobiety, „zebrane pod nieobecność mężczyzn, którzy według autorki zmonopolizowaliby konwersację i nie braliby argumentów przedstawionych przez nie na poważnie"52.

Kolejną cechą świadczącą o wyjątkowej pozycji omawianego utworu w historii gatunku jest to, że tekst wyróżnia się nie tylko na tle wzorcowych jego realizacji autorstwa mężczyzn, ale także wśród dialogów pisanych przez kobiety, które zwykły przedstawiać w swoich tekstach rozmowy określane przez Janet Levarrie Smarr jako dyfoniczne, to znaczy rozgrywające się pomiędzy dwiema bohaterkami, często przyjaciółkami bądź krewnymi ${ }^{53}$. Były to okoliczności dużo bardziej sprzyjające zwierzeniom, dla których liczniejsze zgromadzenia nie byłyby odpowiednie. Fonte do dyskusji wprowadza siedem (podobnie jak w Dekameronie) bohaterek, zróżnicowanych zarówno pod względem wieku, jak i stanu cywilnego ${ }^{54}$. Najstarsza z nich, wdowa Adriana, zostaje wybrana przez koleżanki na „królową” dyskusji. Córka moderatorki debaty, Virginia, jest niezamężna. Leonora, u której spotykają się bohaterki, to młoda wdowa, Cornelia jest młodą mężatką, natomiast Lucrezia - starszą, zamężną kobietą. Corinna, młoda panna, określona jest jako la dimessa, co oznaczało, jak przypomina Janet Levarrie Smarr, „członkinię nowego rodzaju posttrydenckiej instytucji rodzącej się na terenie Veneto dla kobiet chcących prowadzić pobożne

$51 \quad$ Ibidem, s. 248.

52 E. Carinci, Canone, gender genere letterario..., s. 95.

53 J. Levarie Smarr, Joining the Conversation..., s. 2. Warto przypomnieć także dialogi Erazma z Rotterdamu, który tworzył żeńskie bohaterki i podejmował kwestie kobiece. Były to jednak w większości dialogi dyfoniczne, zob. Erasmus on Women...

54 W przypadku utworu Senatulus Erazma, wzorowanego na sztuce Arystofanesa, w którym mamy do czynienia z większą liczbą kobiet (zbiera się sejm niewieści), zgromadzenie wyklucza obecność panien. Fonte prezentuje bardziej zróżnicowaną, otwartą grupę. 
życie w celibacie bez konieczności pójścia do zakonu"55. Siódma z bohaterek, Elena, dopiero co wyszła za mąż. Jej niedawny ślub oraz spowodowana nim dłuższa nieobecność w towarzystwie są pretekstem do spotkania i rozpoczęcia rozmowy na temat mężczyzn. Tak zróżnicowane towarzystwo pozwala Fonte na zaprezentowanie całego wachlarza poglądów i skonfrontowanie ze sobą różnych doświadczeń.

\section{Zabawa-rozrywka}

Wenecjanki u Fonte, tak jak bohaterowie Castiglionego, decydują się na spotkanie i rozmowę dla przyjemności i rozrywki. „Pionierski w artykułowaniu kulturowej teorii gier" ${ }^{36}$ XVI wiek był konsekwencją bogatej kultury ludycznej wczesnonowożytnej Italii, a bujne życie towarzyskie renesansowych elit jednym z przejawów dążenia do "gry sztucznej doskonałości"57. Odzwierciedlało to postrzeganie ludzkiej egzystencji na wzór sztuki. Za taką uchodziła rozmowa, często utożsamiana z zabawą ${ }^{58}$. W czasach Moderaty Fonte na porządku dziennym były słowne gry w rodzaju tej, którą przeprowadzają dworzanie u Castiglionego, polegającej na prowadzeniu dyskusji według określonych na początku spotkania reguł. Taki twórczy sposób spędzania wolnego czasu budził zainteresowanie i podziw także za granicą. I w Polsce zyskał uznanie, o czym przekonuje dzieło Łukasza Górnickiego:

Czemuby też kto nie wniósł owego obyczaju do nas, który jest we Włoszech, iż ślachta zacna, polerując rozumy swoje, wynajduje na biesiedzie gry rozumne i tych używa, w których się nierówno więtsza pociecha i pożytek znajdzie niżeli w karciech ${ }^{59}$.

Fonte wykorzystuje potencjał tego zajęcia do zaangażowania się w querelle des femmes, chociaż ludyczność tej formy spędzania wolnego czasu w przypadku dyskusji o wartości kobiet mogłaby przecież osłabiać podnoszone w niej argumenty:

Prezentowanie się kobiet jako jedzącej i pijącej wspólnie grupy mogłoby podważyć ich wysiłek w kreowaniu wizerunku intelektualistek i mieć efekt zupełnie odwrotny do zamierzonego:

55 J. Levarie Smarr, Joining the Conversation..., s. 216.

56 G. McClure, Parlour Games and the Public Life of Women in Renaissance Italy, Toronto-Buffalo-London 2013, s. 3. Autor dostrzega w XVI wieku w Italii narodziny literatury dotyczącej gier i zabaw. Wymienia między innymi poemat o grze w szachy Girolama Vidy (sparafrazowany przez Jana Kochanowskiego), traktat o grze w tenisa Antonia Scaino czy dialogi Torquata Tassa, w których ten rozważa między innymi rodzaje zabaw, ich cele i płynącą z nich przyjemność. Temat roli kobiet w Gonzaga secondo ovvero del giuoco oraz Il Romero overo del giuoco Tassa McClure rozwinął w studium: Women and the Politics of Play in Sixteenth Century Italy: Torquato Tasso's Theory of Games, „Renaissance Quarterly” 61 (2008), no. 3, s. 750-791.

57 J. Huizinga, Homo ludens..., s. 255.

58 Por. A. Borowski, Rozmowa o sztuce bycia człowiekiem, w: B. Castiglione, Ksiażka..., s. 14.

59 Ł. Górnicki, Dworzanin polski, oprac. R. Pollak, Wrocław 1954 (BN I 109), s. 24. 
ugruntować negatywny stereotyp, wedle którego kobiety kojarzy się z żądzami cielesnymi: obżarstwem, pijaństwem i bliską mu chucią ${ }^{60}$.

Jednym z celów prezentowanego artykułu jest analiza konsekwencji zastosowania konwencji zabawy (gry) dla odbioru dialogu Fonte. Skoro „świat gry w okresie wczesnonowożytnym mógł pełnić wiele funkcji w odniesieniu do społecznej hierarchii”" ${ }^{\prime \prime 1}$, warto dokładnie przyjrzeć się zorganizowanej przez bohaterki zabawie. Pomocna stanie się definicja stworzona przez Johana Huizingę, pozwalająca opisać konwencję, w jakiej wenecka pisarka przedstawia swoje argumenty. W dalszej interpretacji wezmę pod uwagę poszczególne elementy wyróżnione przez Huizingę jako charakterystyczne dla sytuacji ludycznej:

Zabawa jest dobrowolną czynnością lub zajęciem, dokonywanym w pewnych ustalonych granicach czasu i przestrzeni według dobrowolnie przyjętych, lecz bezwarunkowo obowiązujących regul, jest celem sama w sobie, towarzyszy jej zaś uczucie napięcia i radości i świadomość „odmienności” od „Zwyczajnego życia”62.

\section{Wolność kobiet i wolność w grze}

Mimo że role w zabawie od początku są narzucone i każda z kobiet przypisana jest przez Adrianę do jednego ze stronnictw, „królowa gry” stara się je rozdzielać tak, by były zbliżone do stanowisk wyjściowo reprezentowanych przez poszczególne kobiety. Dzięki takiemu podziałowi można oddalić ewentualny zarzut, że bohaterki są w jakikolwiek sposób ograniczane. Zaproponowany przez prowadzącą temat dyskusji „wielce się spodobał” (s. 24) wszystkim towarzyszkom. Żadna z nich nie wyraża też sprzeciwu wobec uczestnictwa w grze, a wszechobecny śmiech i przyjacielska atmosfera są dowodem na to, że gra jest dobrowolna; „nakazana zabawa nie jest już zabawą"63. Ponadto swoboda rozmowy dopuszcza złagodzenie stanowisk i zmianę strony sporu. Janet Levarie Smarr zauważa, że w ten sposób Fonte nadaje bohaterkom pewną autentyczność. Nie przedstawia ich bowiem jako rzeczniczek jednej, niezmiennej postawy, ale portretuje je jako „osoby, które mogą zmieniać zdanie w dyskusji z przyjaciółmi" ${ }^{\prime \prime}$. Wolność w wygłaszaniu poglądów gwarantuje też nieobecność mężczyzn. Wielokrotnie powtarza się argument, że ci wykorzystaliby swoją dominującą w społeczeństwie pozycję do uniemożliwienia kobietom zabrania głosu we własnej sprawie. Mówi o tym na przykład Cornelia:

60 J. Levarie Smarr, Joining the Conversation..., s. 5.

61 G. McClure, Women and the Politics of Play..., s. 751.

62 J. Huizinga, Homo ludens..., s. 48-49.

63 Ibidem, s. 20.

64 J. Levarie Smarr, Joining the Conversation..., s. 217. 
Lodato sia Dio, poiché pur possiamo dire delle piacevolezze così per rider tra noi e far ciò che più ne aggrada, che qui non è chi ci noti o chi ci dia la emenda (s. 16).

[Dzięki Bogu, że możemy żartować i śmiać się między sobą i robić to, co się nam podoba, jako że nie ma tu nikogo, kto by się temu przyglądał i nas poprawiał].

To dzięki takiej gwarancji bezpieczeństwa bohaterki mogą rzeczywiście poruszyć wiele wątków, od rozważania męskich wad, przez refleksje na temat miłości i przyjaźni, pogawędki o lekach, kosmetykach i medycynie, po komentowanie ubioru innych kobiet czy rozmowę dotyczącą jedzenia. Widać więc, że dyskusja nie jest niczym ograniczona, a bohaterki czują się na tyle bezpiecznie, by nie musieć się zastanawiać nad tym, co wypada mówić, a jakich tematów lepiej unikać. Dlatego też Leonora może głośno powiedzieć, że marzy jej się jazda konno i polowanie z sokołem na przepiórki (s. 140).

Swobodna atmosfera w weneckim ogrodzie sprzyja otwartości w dzieleniu się kontrowersyjnymi poglądami, ale też podejmowaniu intelektualnych wyzwań. Takim niewątpliwie było wygłoszenie przez Leonorę obszernej mowy w obronie kobiet, choć sama „królowa gry” przyznaje, że „sztuka oratorstwa nie jest rzeczą łatwą” (s. 76). Gospodyni spotkania przyjmuje rolę rzeczniczki kobiet i w ich imieniu przemawia tak, jakby występowała przed zgromadzeniem mężczyzn. Jednocześnie jest świadoma, że okoliczności, w jakich przychodzi jej popisać się doskonałym opanowaniem zasad retoryki, są wyjątkowe. Tuż po zakończeniu mowy przytacza historię o garncarzu, który wysłał syna na studia i bardzo pragnął, aby ten szybko obronił swą rozprawę dyplomową. By sprawdzić, czy syn jest już gotowy na publiczną dyskusję, zaaranżował „słuchaczy”, ustawiając przed przyszłym doktorem garnki. Przysłuchując się przemowie syna, był pod wielkim wrażeniem jego erudycji i elokwencji, mimo że nie zrozumiał $\mathrm{z}$ wystąpienia ani słowa. Młodzieniec nie był jednak w stanie odpowiedzieć na żadne z pytań zadanych przez prawdziwą publiczność akademicką.

Anegdota, którą Leonora opowiada tuż po zakończeniu oratorskiego popisu, świadczy o niepewności mówczyni, powątpiewaniu w swoje umiejętności i strachu przed ewentualnym wyśmianiem jej przez słuchaczy. Towarzystwo znajomych i życzliwych jej kobiet nie onieśmiela i sprzyja swobodzie wypowiedzi, czego uczestniczki spotkania są świadome. Zdają sobie sprawę z wyjątkowości tej sytuacji. Nie bez wpływu na nią pozostaje także ograniczenie czasu i przestrzeni, czyli kolejna cecha zabawy wskazana przez Huizingę.

\section{Czas i przestrzeń gry}

Bohaterki spotykają się w środku lata, w położonym nad Canale Grande domu Leonory, niedawno odziedziczonym po ciotce. Z jego balkonu wypatrują Eleny, przybywającej gondolą na spotkanie. W przedstawieniu ogrodu gospodyni, w którym kobiety rozmawiają, dostrzegamy realizację toposu miejsca przyjemnego (locus 
amoenus). Tak jak w Dekameronie Boccaccia, w którym bohaterowie, uciekając przed zarazą, schronili się w otoczonej pięknym krajobrazem podmiejskiej wilii, by oddalić się od zagrożenia, rozmówczynie u Fonte znajdują się w miejscu zapewniającym intymność i schronienie przed okrutnym męskim światem. Nieprzypadkowo jako największą zaletę pięknego ogrodu Leonory Corinna wskazuje brak mężczyzn (s. 21).

Locus amoenus z dialogu Fonte trudno jednakże uznać za wzorcową realizację toposu miejsca przyjemnego. Nie jest ono oddalone od miasta, a jego piękno nie wynika $\mathrm{z}$ naturalnego położenia. Jest za to wystarczająco wyodrębnione $\mathrm{z}$ otaczającej je przestrzeni, by móc wywołać - jak podkreśla Ernst Robert Curtius - niewyjaśnione nigdy dokładnie poczucie piękna przyrody ${ }^{65}$. Autorka pisze (s. 19): „[...] non si potrebbe esprimere con lingua quanto parve loro vaghissimo e delizioso" („[...] nie sposób opisać tego, co wydało im się pełne uroku i słodyczy”). Rajski ogród Leonory, pełen kolorów i zapachów, obfituje w roślinność we wszystkich kształtach i rozmiarach. Doznania zmysłowe urozmaica unosząca się woń dojrzałych cytryn i pomarańczy. Cyprysy mogą zapewnić przydatny do pisania wierszy cień, zachęcając w ten sposób do oddania się twórczości, a ważne dla toposu miejsca przyjemnego źródło zastępuje położona w centrum ogrodu fontanna. Jej forma jest dla tematu dialogu bardzo znacząca: odzwierciedla sposób, w jaki zdecydowała się prowadzić swoje życie poprzednia właścicielka ogrodu, ciocia Leonory, przeciwniczka mężczyzn, która zgodnie ze swoim postanowieniem nie wyszła nigdy za mąż. Fontannę tworzą posągi kobiet. W lewej ręce każda trzyma oliwną gałązkę, do której przypięty jest mały zwój z inskrypcją, pełniącą funkcję komentarza do atrybutów trzymanych przez figury w ręce prawej. Leonora, oprowadzając koleżanki po ogrodzie, tłumaczy im znaczenie poszczególnych symboli, łącząc je z cechami cioci i sposobu życia, jaki wybrała. Gronostaj ilustruje niewinność, Feniks - samotność i indywidualizm, ale także zdolność do odradzania się, chociażby dzięki sztuce, dziełom, które można po sobie zostawić. Ciocia Leonory, jak Słońce, trzymane przez kolejną z przestawionych na fontannie kobiet, dzieliła się swoim blaskiem ze światem, co nie byłoby nigdy możliwe, gdyby została poskromiona przez męża. Skończyłaby wtedy jak motyl w płomieniach, będący atrybutem kolejnej z postaci i symbolizujący kobiecą naiwność, uleganie mężczyznom, często pełnym fałszu. Ten symbolizowany jest przez przypisaną następnej figurze brzoskwinię, kształtem przypominającą serce i z liściem wyglądającym jak język, za pomocą którego, jak tłumaczy gospodyni, mężczyźni łudzą kobiety, ukrywając swe prawdziwe zamiary. Ostatni symbol, krokodyl, ilustruje okrucieństwo mężczyzn, którzy dręczą kobiety, by potem udawać miłosiernych.

Ogród Leonory i znajdujące się w nim elementy okazują się symboliczne, mogą więc stanowić przestrzeń do interpretacji. Miejsce staje się w ten sposób nieprzypadkową scenerią dla querelle des femmes i współgra z tematyką dialogu. Zwraca uwagę także staranne zaprojektowanie ogrodu i dbałość o detale. Nic nie jest w nim nie na

65 Por. E.R. Curtius, Literatura europejska i łacińskie średniowiecze, przeł. i oprac. A. Borowski, Kraków 2005, s. 192. 
miejscu. Nawet liście są przycięte tak, by żaden nie wystawał ponad inne. Ogród jest kreacją, nie pozostawia przestrzeni dla tego, co dzikie. Naturalne uwarunkowania w pewien sposób wpływają jednak na długość dyskusji: bohaterki przerywają ją wraz z zachodem słońca, by wznowić rozważania następnego dnia. Przestrzeń charakteryzuje jednak sztuczność. Dominują w niej ład oraz wyznaczony porządek, a przyroda jest poskromiona i poddana kontroli.

\section{Posłuszeństwo wobec reguł gry}

Kontrola w zabawie polega na wyznaczeniu jej reguł. Dyskusję bohaterek Fonte moderuje najstarsza z zebranych, Adriana. Ciekawy jest sposób wyboru „królowej gry”. Ze względu na wiek (przekroczyła pięćdziesiąt lat), doświadczenie i łagodny charakter otrzymuje wyjątkową pozycję niejako „z urzędu”. Inaczej w Dekameronie: tam każdy z uczestników zebrania bierze udział w wyborach na to stanowisko. Według Virginii Cox hierarchia niewielkiej grupy w literackich dialogach jest uzależniona od ustroju politycznego, w jakim powstawały. I tak też republikańskie tradycje Florencji da się dostrzec w organizacji dyskusji uciekinierów u Boccaccia, a w dialogu Fonte przywódczynię wybiera się niczym weneckiego dożę ${ }^{66}$. Autorytet Adriany nie jest ani przez moment kwestionowany, a kobiety czują potrzebę zorganizowania się pod czyimś przywództwem, ponieważ bez liderki nie są w stanie nawet wybrać tematu dyskusji:

Di grazia - disse Corinna - ellegiamo tra noi una, che commandi alle altre e sia ubidita; perchè invero la ubidienza così in una casa, come in una città è non pur utile, ma necessaria quanto altra virtù e così verremo ad esser tutte conformi di volere (s. 23).

[Wybierzmy - powiedziała Corinna - jedną z nas na przewodniczkę i bądźmy jej posłuszne; ponieważ doprawdy posłuszeństwo tak w domu, jak i w mieście, jest nie tylko potrzebną, ale i niezbędną cnotą, by połączyć pragnienia nas wszystkich].

Corinna podkreśla tym samym potrzebę posłuszeństwa dla osiągnięcia harmonii. Ten aspekt jest niezmiernie istotny także w kontekście argumentów w obronie godności kobiet. Bohaterki dialogu Fonte wielokrotnie narzekają na przymus posłuszeństwa wobec mężów. Ciekawe, że dyskutujące o męskich wadach kobiety z początku w ogóle nie rozważają koncyliacyjnego rozwiązania: próbują udowodnić swą wyższość nad mężczyznami. Odwracają na przykład spojrzenie na sytuację, kiedy kobieta zajmuje się domem, podczas gdy jej mąż walczy i zapewnia rodzinie byt. Nie oznacza to bynajmniej jego dominacji. Taki mężczyzna jest według nich po prostu na usługach żony:

66 V. Cox przypis nr 21, w: M. Fonte, The Worth of Women..., s. 56-57. 
[...] dovremmo noi avere sopra di loro; poichè si vede chiaramente che'loro proprio è di andarsi a faticar fuor di casa e travagliarsi per acquistarci le facoltà, come fanno a punto i fattori o castaldi, acciò noi stiamo in casa a godere e commandare come patrone; e perciò sono nati più robusti e più forti di noi, acciò possino sopportar le fatiche in nostro servizio (s. 26).

[Powinnyśmy nad nimi górować; widać przecież wyraźnie, że ich obowiązkiem jest męczenie się z dala od domu i wysilanie się w zdobywaniu umiejętności, jakby byli jedynie dodatkiem do nas lub naszymi sługami, my w tym czasie jesteśmy w domu, by cieszyć się życiem i dowodzić jako właścicielki; z tego powodu mężczyźni urodzili się bardziej krzepcy i silniejsi od nas, aby mogli znieść ten wysiłek w służbie nam].

Tak mówi Corinna na początku zebrania, uświadamiając nam, jak rozmaite mogą być interpretacje tej samej sytuacji w zależności od tego, po której ze stron sporu się znajdujemy, i jak bardzo nasze poglądy mogą determinować postrzeganie świata. Czytelnik często ma tu do czynienia ze skrajnymi stanowiskami. Wspomniałam już, że zasady tej zabawy sprzyjają swobodnej zmianie stanowisk. Zdania w kwestii podporządkowania i dominacji zostają pod koniec dialogu złagodzone do tego stopnia, że wygłaszająca mowę Leonora, poparta - co warto podkreślić - przez wszystkie zebrane w jej ogrodzie kobiety, mówi wręcz o chęci służenia mężczyznom:

A ciò instando ancora la nostra umiltà, pazienza e bontà con tanti altri meriti, per li quali ragionevolmente doviamo esser amate; con l'oblazion, che al presente vi facciamo di rimetterci e dimentcarci tutte l'offese passate e di esservi più che mai per l'avenir amorevoli e sogette, per amore però e non per forza. Ch’amor regge suo imperio senza spada (s. 134).

[Do tego jeszcze nasza pokora, cierpliwość i dobroć, jak i inne liczne cnoty, za które słusznie powinnyśmy być kochane; jesteśmy gotowe ponieść tę ofiarę - spotkać się dziś i zapomnieć o wszystkich dawnych urazach, a także być bardziej niż kiedykolwiek kochające i wam podległe - z miłości jednak, nie z przymusu. Miłość rządzi bowiem swoim królestwem bez miecza].

Leonora podkreśla, że podległość mężczyźnie wynikać ma nie z obowiązku, a dobrowolnej miłości, dzięki której życie wedle określonych reguł nie jest wynikiem żadnej presji. Cel kobiet z dialogu Fonte nie wydaje się w kontekście tych słów rewolucyjny. Nie chcą na przekór wszystkiemu podporządkować sobie mężczyzn. Hierarchii i obowiązku nie kojarzą jednak jednoznacznie z przymusem i uciskiem.

Widać to także w bardzo pozytywnym stosunku bohaterek do instytucji władzy. O weneckim doży, a także o innych mężczyznach obdarzonych talentami, wypowiadają się z dużym szacunkiem i uznaniem:

Sempre - disse Lucrezia - questo aventuroso dominio si è governato con gran sapienza e sempre ha avuto uomini di gran senno e di gran bontà nel regger e deteminr le cose di esso, come anco a nostri tempi si trovano aver oltra sì eccelente prencipe, tanti valorosi 
conseglieri, procuratori, savi, avogadori e censori e tanto illustre numero di eccelentissimi magistrati (s. 143).

[Zawsze - powiedziała Lucrezia - ta władza była sprawowana z wielką mądrością oraz przez mężczyzn o wielkim rozsądku i wielkiej dobroci w zarządzaniu i stanowieniu prawa; tak też wciąż w naszych czasach oprócz tego, że mamy doskonałego księcia, wielu jest wybitnych doradców, zarządców, uczonych, adwokatów, sędziów i licznych wspaniałych urzędników].

Wraz z rozwojem dyskusji początkowa gorliwość w wynajdowaniu męskich wad i przywoływanie kolejnych argumentów mających dowodzić wyższości kobiet nad płcią przeciwną ustępują przychylnym wypowiedziom na temat mężczyzn. Mowa Leonory, która początkowo miała atakować mężczyzn, broni podziału domowych obowiązków i odbiega od wcześniejszych wypowiedzi bohaterki; przebijała z nich chęć zdominowania mężczyzn i dowiedzenia, zgodnie z podtytułem dialogu, że kobiety są od nich doskonalsze. Według gospodyni spotkania dominacja czy posłuszeństwo nie muszą nosić znamion jakiejkolwiek opresyjności. Jak zabawa nie traci na swobodzie i nie ogranicza wolności wypowiedzi uczestniczek, mimo że odbywa się w zgodzie z „dobrowolnie przyjętymi, lecz bezwarunkowo obowiązującymi regułami”, tak i wolność kobiet mogłaby nie być zagrożona, gdyby tylko mężczyźni odnosili się do nich z szacunkiem, a obowiązujące w domu zasady były wynikiem wspólnej decyzji motywowanej miłością.

\section{Niezwyczajność}

Na potrzeby zabawy tworzy się „osobny, czasowo tylko obowiązujący świat”" ${ }^{\text {. Towa- }}$ rzyszy jej poczucie wyjątkowości i ucieczki od zwyczajnego życia, jak w opisywanym przez Michaiła Bachtina karnawale, kiedy „zostają zawieszone prawa, zakazy i ograniczenia utrzymujące porządek zwykłego, pozakarnawałowego świata"68 ${ }^{\text {"Podobnie }}$ dzieje się w dialogu Fonte: bohaterki są świadome, że po zakończeniu dyskusji powrócą do codzienności sprzed spotkania.

Gdy Virginia jeszcze przed rozpoczęciem dyskusji i ustaleniem reguł gry mówi, że wolałaby nie mieć męża, od razu spotyka się ze sprzeciwem matki, Adriany, która nie pozostawia jej żadnych wątpliwości: ze względu na spory majątek, który córka kiedyś odziedziczy, dziewczyna nie ma innego wyjścia - musi wyjść za mąż. Po oficjalnym zakończeniu debaty, która pozostaje przecież nierozstrzygnięta, jej przewodnicząca dziękuje zebranym za respektowanie zasad. Nie zmienia swego stanowiska sprzed dyskusji; próbuje przekonać Leonorę do zmiany zdania na temat małżeństwa i namawia ją do znalezienia godnego towarzysza. Wreszcie kobiety żegnają się, jak gdyby nigdy nic, i odchodzą, aby wrócić do swoich domów, do codziennego życia.

67 J. Huizinga, Homo ludens..., s. 29.

68 M. Bachtin, Problemy poetyki Dostojewskiego, przeł. N. Modzelewska, Warszawa 1970, s. 188. 
Podtytuł dialogu sugerujący „oczywistą” wyższość kobiet nad mężczyznami nie znajduje potwierdzenia w zakończeniu utworu i nadaje mu ironiczny charakter. Wygląda bowiem na to, że pełna radości ze wspólnie spędzonego czasu gra może być dla bohaterek „celem samym w sobie”, a uczestniczące w niej kobiety nie aspirują naprawdę do zmiany status quo.

\section{Rozważania końcowe}

Nawet jeśli w obrębie tekstu zabawa nie służy konkretnemu celowi, przyjęcie szerszej perspektywy - książka ukazała się drukiem, czyli niejako przekroczyła granice wyznaczone przez ogród Leonory - pozwala uzasadnić funkcjonalność konwencji wybranej przez Fonte. Dzięki niej uczestniczki dialogu mogą mieć większą swobodę i wyjątkowe poczucie wolności, umożliwiające im niekrycie się ze swoimi poglądami. Konwencja ta pozwala także samej autorce na stworzenie dystansu wobec prezentowanych stanowisk. Skoro zabawa „istnieje poza dysjunkcją «mądrość - głupota», ale tak samo poza dysjunkcją "prawda - nieprawda», bądź też «dobro - zło»" wszystko, co podczas niej się wydarza, można wziąć w nawias i dzięki temu osłonić się przed zarzutami o zbyt odważne poglądy. Te bywają w dziele Fonte skrajne i pozbawione argumentacji. Przykładem mogą być uwagi o mężczyznach, których bohaterki uznają za „najbardziej fałszywych ludzi” (s. 18), „nigdy niemówiących prawdy, chyba że przez przypadek" (s. 41). Podobnie jest podczas dyskusji o faunie i florze, gdy bohaterki usiłują połączyć rozmowę o zjawiskach przyrody z udowadnianiem męskiej niższości i porównują przedstawicieli płci przeciwnej do kwiatów, które nie wydają owoców (s. 120), lub stworzeń o dwudziestu pięciu głowach (s. 8788). Dialog zyskuje w ten sposób wydźwięk humorystyczny. Dzięki temu dobrze bawią się nie tylko bohaterki książki, ale i czytelnik. Jak zauważyła Virginia Cox:

Zignorowanie humoru Il merito delle donne byłoby przeoczeniem zarówno znaczenia, jak i uroku dialogu Fonte. Tak samo pominięcie powagi, która pojawia się w podtekście nawet najzabawniejszych momentów byłoby niedocenieniem złożoności dzieła, z pozoru spontanicznego i bezpośredniego ${ }^{70}$.

"Zabawa doskonale może być poważna”71, twierdził Huizinga. W Dworzaninie polskim pojawia się uwaga, że „z takowych gier siła jeden wziąć sobie w głowę może”72. U Fonte dzięki grze zyskujemy - zupełnie na serio - wiedzę na temat argumentów wczesnonowożytnego sporu o kobiety.

\footnotetext{
69 J. Huizinga, Homo ludens..., s. 19.

70 V. Cox, Moderata Fonte..., s. 17.

71 J. Huizinga, Homo ludens..., s. 17.

72 Ł. Górnicki, Dworzanin..., s. 26.
} 
Forma dialogu nie tylko pozwala na zaprezentowanie zróżnicowanych stanowisk na tle ówczesnego stanu wiedzy o świecie, ale także ułatwia autorce ukazanie pisarskiego kunsztu przez sprawne posługiwanie się retoryką, włączanie w dyskusję „spontanicznie” wymyślanych przez bohaterki wierszy czy wzorcowej mowy Leonory. Fonte uświadamia, że stworzone przez mężczyzn zasady formułowania wypowiedzi mogą być indyferentne; są jedynie narzędziami, które nie muszą faworyzować żadnej z płci. Dlatego nieuzasadnione jest wyłączanie kobiet z publicznej debaty czy pozbawienie ich możliwości studiowania. Pisarka wyraża kobiece aspiracje do partycypowania w świecie nauki, a ponadto udowadnia, że tematy podejmowane przez uczonych mogą być żywo dyskutowane poza uniwersyteckimi murami i bynajmniej nie tracą ważności z tego powodu, że towarzyszą im rozmowy o stroju czy kosmetykach. Moderacie Fonte udało się połączyć spór o kobiety z praktycznym życiem; dzięki dialogowi uczona dyskusja zyskuje przystępny w odbiorze charakter i nie jest jedynie erystycznym ćwiczeniem uprawianym w oderwaniu od realnych problemów.

Konwencja dialogu pozwala także na usprawiedliwienie zakończenia, które nie przynosi jasnego rozwiązania sporu. Sugerowaną w podtytule wyższość kobiet zastępuje w mowie Leonory podkreślenie faktu, że z natury kobiety i mężczyźni są sobie równi, a gra nie kończy się rozstrzygnięciem na korzyść którejś ze stron. Zostaje przerwana nie z powodu wypracowania konkluzji, ale zachodu słońca, który stanowi znak, że nadchodzi czas na powrót do domów. Oczekujący dowodu na wyższość jednej z płci czytelnik mógłby czuć się rozczarowany. Myślę, że mało wyraziste zakończenie nie świadczy o palinodycznym charakterze tekstu. Nie wynika też z braku wyrobienia literackiego autorki - wręcz przeciwnie - takie zakończenie doskonale koresponduje z formą utworu. Wytrąca umysł z gnuśności i pobudza do zaangażowania się w dyskusję. Dialog zakłada wyjście poza poziom tekstu. Nie służy wyłożeniu gotowych rozwiązań; nie zwalnia z samodzielnego rozumowania. Gdyby Fonte swoje poglądy przedstawiła za pomocą traktatu, wyłączyłaby czytelnika z debaty. Sama też zostałaby przypisana do któregoś ze stanowisk. Forma dialogu sprawia nie tylko, że trudno zidentyfikować poglądy autorki (można argumentować za tym, że ukrywa się pod postacią Corinny, zawsze jednak będzie to tylko przypuszczenie), ale także że głos pisarki w sporze o kobiety jest angażujący również po zakończeniu zabawy.

Jasna wydaje się w tym kontekście odpowiedź na postawione na początku pytanie o wyjątkowość dialogu Il merito delle donne na tle innych tekstów reprezentatywnych dla wczesnonowożytnego sporu o kobiety - wpisując się w literacką tradycję dialogu, różni się on od charakterystycznych realizacji tego gatunku, zarówno w wydaniu mężczyzn, jak i kobiet. Moderata Fonte proponuje oryginalne ujęcie tematu, mimo że prezentowane przez poszczególne bohaterki poglądy są wtórne wobec znanych wówczas stanowisk. Czyni to, ukazując swe postaci w konwencji umożliwiającej im swobodę wymiany zdań i wprowadzając element zabawy. Podejmuje także grę z czytelnikiem oczekującym wyraźnego stanowiska autorki. Rozproszony, wydawałoby się, głos Moderaty Fonte, staje się dzięki tym zabiegom głosem zapraszającym do dyskusji. 


\section{Bibliografia}

\section{Źródła}

Boccaccio G., Dekameron, przeł. E. Boyé, Kraków 2017.

Boccaccio G., O stynnych kobietach, przeł. i oprac. P. Bańkowski, I. Grześczak, A. Szopińska, Warszawa 2013.

Castiglione B., Książka o dworzaninie, przeł. A. Borowski, Kraków 2018.

Doglioni N., Vita della signora Modesta Pozzo de Zorzi nominata Moderata Fonte descritta da gio. Nicolò Doglioni l'anno M. D. XCIII, w: M. Fonte, Il merito delle donne ove chiaramente si scuopre quanto siano elle dengne e più perfette de gli uomini, a cura di A. Chemello, Venezia 1988, s. 3-10.

Fonte M., Il merito delle donne ove chiaramente si scuopre quanto siano elle dengne e più perfette de gli uomini, a cura di A. Chemello, Venezia 1988.

Fonte M., The Worth of Women: Wherein Is Clearly Revealed Their Nobility and Their Superiority to Men, ed. and transl. by V. Cox, Chicago-London 1997.

Del giardino de'poeti, in lode del Serenissimo Re di Polonia, Gran Duca di Littuania, Russia, Prussia, Samogita, e Chiouiua, Signor di Libonia \& Prencipe di Transilvania, Venezia 1583.

Górnicki Ł., Dworzanin polski, oprac. R. Pollak, Wrocław 1954 (BN I 109).

\section{Opracowania}

Ackroyd P., Wenecja. Biografia, przeł. T. Bieroń, Poznań 2015.

Bachtin M., Problemy poetyki Dostojewskiego, przeł. N. Modzelewska, Warszawa 1970.

Bachtin M., Twórczość Franciszka Rabelais'go a kultura ludowa średniowiecza i renesansu, przeł. A. i A. Goreniowie, oprac. S. Balbus, Kraków 1975.

Bardi G., Delle cose notabili della città di Venetia, Venetia: Felice Valgrisi,1587, https://archive. org/details/imageGXII204NarrativaOpal/page/n9 (dostęp: 1.06.2019).

Bogucka M., Gorsza płeć. Kobieta w dziejach Europy od antyku po wiek XXI, Warszawa 2005. Boni F., «VII: Foetorem in lecto» Una lettura de "I donneschi difetti" di Giuseppe Passi Ravennante, „Studia Litteraria Universitatis Iagellonicae Cracoviensis” 5 (2010), issue 1, s. 25-36.

Borowski A., Rozmowa o sztuce bycia człowiekiem, w: B. Castiglione, Ksiażka o dworzaninie, przeł. A. Borowski, Kraków 2018.

Burckhardt J., Kultura odrodzenia we Włoszech, przeł. M. Kreczkowska, Warszawa 1991.

Callois R., Gry i ludzie, przeł. A. Tatarkiewicz, M. Żurowska, Warszawa 1997.

The Cambridge Companion to Early Modern Women's Writing, ed. by L.L. Knoppers, Cambridge 2009.

Carinci E., Canone, gender genere letterario: «Il merito delle donne» di Moderata Fonte, w: Dentro/Fuori Sopra/Sotto. Critica femminista e canone letterario negli studi di italianistica, Ravenna 2007. 
Chemello A., Gioco e dissimulazione in Moderata Fonte, w: M. Fonte, Il merito delle donne ove chiaramente si scuopre quanto siano elle dengne e più perfette de gli uomini, a cura di A. Chemello, Venezia 1988.

Chemello A., Il nuovo «canone di lettura» di Luisa Bergalli: «I Componimenti poetici più illustri Rimatrici d'ogni secolo», w: Voci e figure di donne. Forme della rappresentazione del sé tra passato e presente, a cura di L. Fortini, M. Sarnelli, Cosenza 2012.

Conti Odoriso G., Donna e societa nel Seicento. Lucrezia Marinelli e Arcangela Tarabotti, Roma 1979.

Cox V., Moderata Fonte and "The Worth of Women", w: M. Fonte, The Worth of Women: Wherein Is Clearly Revealed Their Nobility and Their Superiority to Men, ed. and transl. by V. Cox, Chicago-London 1997, s. 1-23.

Cox V., The Prodigious Muse: Women's Writing in Counter-Reformation Italy, Baltimore 2011.

Cox V., Women's Writing in Italy 1400-1650, Baltimore 2008.

Curtius E.R., Literatura europejska i łacińskie średniowiecze, przeł. i oprac. A. Borowski, Kraków 2005.

Encyclopedia of Women in the Renaissance: Italy, France and England, ed. by D. Robin, A.R. Larsen, C. Levin, Santa Barbara-Denver-Oxford 2007.

Erasmus on Women, ed. by E. Rummel, Toronto-Buffalo-London 1996.

Fantazzi Ch., Vives and the "emarginati", w: A Companion to Juan Luis Vives, Leiden-Boston 2008, s. 65-111.

Huizinga J., Homo ludens. Zabawa jako źródło kultury, przeł. M. Kurecka, W. Wirpsza, Warszawa 1985.

King M.J., Rabil Jr A., The Other Voice in Early Modern Europe: Introduction to the Series, w: M. Fonte, The Worth of Women: Wherein Is Clearly Revealed Their Nobility and Their Superiority to Men, ed. and transl. by V. Cox, Chicago-London 1997.

Kolsky S., Moderata Fonte, Lucrezia Marinella, Giuseppe Passi: An Early Seventeenth-Century Feminist Controversy, „The Modern Language Review” 96 (2001), no. 4, s. 973-989.

Levarie Smarr J., Joining the Conversation: Dialogues by Renaissance Women, Michigan 2005.

Martelli D., Polifonie: le donne a Venezia nelletà di Moderata Fonte (seconda metà del secolo 16.), Padova 2011.

McClure G., Parlour Games and the Public Life of Women in Renaissance Italy, TorontoBuffalo-London 2013.

McClure G., Women and the Politics of Play in Sixteenth Century Italy: Torquato Tasso's Theory of Games, „Renaissance Quarterly” 61 (2008), no. 3, s. 750-791.

Nowak-Dłużewski J., Okolicznościowa poezja polityczna w dawnej Polsce. Pierwsi królowie elekcyjni, Warszawa 1969.

Partyka J., „Żona wyćwiczona”. Kobieta pisząca w kulturze XVI i XVII wieku, Warszawa 2004. Plebani T., Il «genere» dei libri. Storie e rappresentazioni della lettura al femminile e al maschile tra Medioevo ed età moderna, Milano 2001.

Plebani T., Le scritture delle donne in Europa. Pratiche quotidiane e ambizioni letterarie (secoli XIII-XX), Roma 2019.

Plebani T., Scritture delle donne nel Rinascimento italiano, w: Il Rinascimento Italiano e l'Europa, vol. 2: Umanesimo ed educazione, a cura di G. Belloni, R. Drusi, Vicenza 2007, s. 243-263. 
Ray M.K., Daughters of Alchemy: Women and Scientific Culture in Early Modern Italy, Cambridge (Mass.) 2015.

Romagnoli A., La donna del Cortegiano nel contesto della tradizione (Tesis de Doctorato, Universidad de Barcelona 2009).

Romanello M., Doglioni, Giovanni Niccolò, w: Dizionario Biografico degli Italiani, vol. 40 (1991), http://www.treccani.it/enciclopedia/giovanni-nicolo-doglioni_(Dizionario-Biografico) (dostęp: 17.01.2020).

Ross S., Fonte, Moderata (Modesta da Pozzo, 1555-1592), w: Encyclopedia of Women in the Renaissance: Italy, France and England, ed. by D. Robin, A.R. Larsen, C. Levin, Santa Barbara-Denver-Oxford 2007.

Sutton-Smith B., The Ambiguity of Play, Cambridge (Mass.) 1997.

„Terminus” 18 (2016), z. 2. (39) (Wczesnonowożytna literatura kobieca 1), z. 3 (40) (Wczesnonowożytna literatura kobieca 2).

Turner V., From Ritual to Theatre: The Human Seriousness of Play, New York 1982.

Uliński M., Kobieta i mężczyzna. Dzieje refleksji filozoficzno-społecznej, Kraków 2001.

Vigliante M., Dal Pozzo, Modesta, w: Dizionario Biografico degli Italiani, vol. 32 (1986), http://www. treccani.it/enciclopedia/modesta-dal-pozzo_(Dizionario-Biografico) (dostęp: 31.05.2019).

\section{MAJA SKOWRON}

仓) Uniwersytet Jagielloński w Krakowie / Jagiellonian University in Kraków, Poland

(D) https://orcid.org/0000-0001-7525-4353

@ ms.skowron[at]student.uj.edu.pl

Maja Skowron-Jagiellonian University Student (Inter-faculty Individual Studies in the Humanities), Pedagogical University of Kraków (Italian philology), second-cycle degree. Research interest: Renaissance literature in Italy. Publications: "Druga Gryzelda? Poskromienie złośnicy a nowela Boccaccia”, Roman. Czasopismo studentów UJ, no. 19 (2019); “Twórczość Nikosa Kazantzakisa a myśl Fryderyka Nietzschego - wokół Greka Zorby”, Artes. Prace roczne studentów Międzywydziałowych Indywidualnych Studiów Humanistycznych Uniwersytetu Jagiellońskiego (2018).

The article is supported by the Erasmus+ Program (no. 37.409400.454.2018). 